\title{
Colchicine Quantification in Salt Stress Treated Culture of Colchicum Iuteum Baker by High Pressure Liquid Chromatography
}

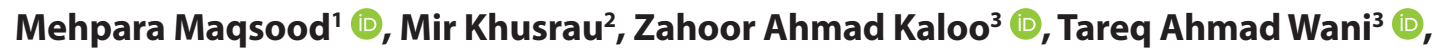

\author{
Abdul Mujib 4 (D) \\ 'Government College for Women, M.A. Road, Srinagar, Jammu \& Kashmir \\ ${ }^{2}$ Government Degree College (Boys), Anantnag, Jammu \& Kashmir \\ ${ }^{3}$ University of Kashmir, Department of Botany, Hazratbal, Srinagar, Jammu \& Kashmir \\ ${ }^{4}$ Department of Botany, Jamia Hamdard, New Delhi, India
}

ORCID IDs of the authors: M.M. 0000-0002-0966-2946; Z.A.K. 0000-0002-1968-476X; T.A.W. 0000-0002-1530-7027;

A.M. 0000-0002-4104-6887

Please cite this article as: Maqsood M, Khusrau M, Kaloo ZA, Wani TA, Mujib A. Colchicine Quantification in Salt Stress Treated Culture of Colchicum luteum Baker by High Pressure Liquid Chromatography. Eur J Biol 2020; 79(2): 67-74.

DOI: 10.26650/EurJBiol.2020.0013

\begin{abstract}
Objective: The aim of the present work was to develop a protocol for season independent propagation of Colchicum luteum and enrichment of colchicine yield under salt stress.

Materials and Methods: C. luteum was collected from Kashmir, India and was cultured in vitro. The callus was exposed to different $\mathrm{NaCl}$ (salt) treatments and the yield of colchicine was quantified by high pressure liquid chromatography (HPLC).

Results: Different explants viz. seeds, leaves, anthers and corm were used and the callus was only induced from corm segments. The callus induction and proliferation were best achieved on Murashige and Skoog medium supplemented with $2.0 \mathrm{mg} \mathrm{L}^{-1} 2,4-\mathrm{D}+4.0 \mathrm{mg} \mathrm{L}^{-1} \mathrm{BAP}$. Direct and indirect plant regeneration from corm was observed in $2.0 \mathrm{mg} \mathrm{L}^{-1} \mathrm{BAP}+2.0 \mathrm{mg}$ $\mathrm{L}^{-1} \mathrm{NAA}$ added medium. The addition of adjuvants like activated charcoal and citric acid was noted to be less efficient for improving callus growth. Induced callus was elicitated with different $\mathrm{NaCl}$ concentrations ( $\mathrm{T}_{0}=$ without $\mathrm{NaCl}, \mathrm{T}_{1}=25, \mathrm{~T}_{2}=50$, $\mathrm{T}_{3}=75$, and $\mathrm{T}_{4}=100 \mathrm{mM}$ ). The yield of colchicine was quantified by HPLC at periodic intervals $(2,4$, and 6 weeks). All the used levels improved colchicine yield, but the content was maximum at $T_{3}\left(871.4 \mathrm{ng} \mathrm{mg}^{-1} \mathrm{DWB}\right)$. This is the first report of callus induction and plant regeneration from corm and the quantification of colchicine under salt stress in C. luteum.
\end{abstract}

Conclusion: Sodium chloride is thus a potential inducer and elicitor in improving colchicine yield in C. luteum.

Keywords: Colchicum luteum, exudates, regeneration, colchicine, in vitro cultures, stress

\section{INTRODUCTION}

Colchicum luteum Baker is rare to Jammu and Kashmir and belongs to the family Colchicaceae (1). It is commonly known as "Suranjan" or "Hirantutiya" and in Kashmir the plant is known as "Vir keom". The plant is popularly found on the edges of sub alpine forests and in open meadows in the temperate western Himalayas extending from Kashmir to Chamba at altitudes of between 700 and $2800 \mathrm{~m}$. The plant bears conical-shaped corm with a middle groove, running longitudinally along its flat side, rapier (elongated and pointed) leaves, short scape and bright yellow flowers. The corms are wrapped with a dark brown thin cover, flattened on one side while the other side is rounded. Leaves are fewer in number and are approximately $15-30 \mathrm{~cm}$ in length and $0.8-1.5 \mathrm{~cm}$ broad. The alkaloid colchicine is extracted from C. luteum (2), and is used for 
the treatment of various diseases like Behçet's syndrome (3) and gout - also known as "rich man's disease". C. luteum possesses anti cancerous activity due to colchicine and demecolcine (4). The corms of C. luteum are antinociceptive and anti inflammatory (5).

Seed propagation of $C$. luteum is rather difficult because of its hard coat, low germination rate and long juvenile stage of about five years (6). Because of these difficulties in seed based propagation, young corms could be used as a good alternative source of different Colchicum species (7). Colchicine is used widely in plant improvement programmes and because of its other medicinal applications there arises an urgent need to conserve plant sources in vitro and ex situ. In vitro micro propagation provides a sensible technique for the conservation of rare and endangered plants (8).

The objective of the present work was to design a method for propagation of $C$. luteum and to enrich colchicine levels in cultivated tissues under $\mathrm{NaCl}$ elicitation/stress. To our best knowledge there is no report on callus culture from corm sections in C. luteum. The effect of salt stress in regulating the colchicine yield was also described.

\section{MATERIALS AND METHODS}

\section{Collection of Plant Material}

Colchicum luteum Baker plants (10 accessions each) were collected from different locations viz., Sonmarg, Gulmarg, Awantipora, Ferozpur, Apharwat and Kralisangri of Kashmir province. The plants were very similar apart for one or two morphological attributes (corm, perianth). Plant material was authenticated and the herbarium of the same was submitted to the Centre for Biodiversity and Taxonomy, University of Kashmir, bearing voucher no. 2212-KASH.

\section{Surface Sterilization of Explants}

Different explants viz. leaves, corms, perianth, filaments, anthers and seeds were used during the present study. The explants were kept under running tap water for 30-45 min, the corms however, required more time (45-60 $\mathrm{min}$ ). Later these explants were kept in labolene and tween for a further $15 \mathrm{~min}$. The explants were sterilized with double distilled water to remove the traces of detergents and dipped in $70 \%$ ethanol for $5 \mathrm{~min}$, followed by washing with double distilled water multiple times to remove the traces of ethanol. Afterwards, these explants (other than corms) were surface sterilized in $4 \%$ sodium hypochlorite (10 $\mathrm{min}$ ) while the corms were dipped in $0.1 \%$ mercuric chloride $\left(\mathrm{HgCl}_{2}\right)$ for $20 \mathrm{~min}$ and washed 3-4 times by using autoclaved double distilled water under a laminar hood. The surface disinfected explants were inoculated in Murashige and Skoog (MS) (9) medium fortified with different plant growth regulators (PGRs). In some cases, citric acid and activated charcoal were used as adjuvants to analyze their influence on callus initiation and other in vitro morphogenesis process.

\section{Callus Induction, Proliferation and Regeneration}

MS medium was used for the initiation of cultures. Before inoculation, the incised corm sections were first put into autoclaved water for $15 \mathrm{~min}$ to leach out alkaloids or other materials that would otherwise interfere with growth. After inoculation, the cultures were placed in an incubation room and were exposed to $16 \mathrm{~h}$ of photoperiodism. The MS medium used for the establishment of culture was supplemented with different PGRs. The different concentrations and combinations of PGRs were $0.5 \mathrm{mg} \mathrm{L}^{-1}$ 2, 4-D, $0.5 \mathrm{mg} \mathrm{L}^{-1} \mathrm{NAA}, 0.5 \mathrm{mg} \mathrm{L}^{-1} \mathrm{BAP}, 0.5$ $\mathrm{mg} \mathrm{L}^{-1} 2,4-\mathrm{D}+0.5 \mathrm{mg} \mathrm{L}^{-1} \mathrm{BAP}, 1.0 \mathrm{mg} \mathrm{L}^{-1} 2,4-\mathrm{D}+1.0 \mathrm{mg} \mathrm{L}^{-1} \mathrm{BAP}$, $0.5 \mathrm{mg} \mathrm{L}^{-1} 2,4-\mathrm{D}+0.5 \mathrm{mg} \mathrm{L}^{-1} \mathrm{NAA}$ and $1.0 \mathrm{mg} \mathrm{L}^{-1} 2,4-\mathrm{D}+1.0$ $\mathrm{mg} \mathrm{L}^{-1} \mathrm{NAA}$. To initiate and proliferate callus at higher rate, other physico-chemical parameters tried were the effect of red light and the effect of $\mathrm{GA}_{3}\left(0.25,0.50\right.$ and $\left.1.0 \mathrm{mg} \mathrm{L}^{-1}\right)$.

\section{Scanning Electron Microscopy (SEM)}

For SEM. callus with somatic embryos were collected from sub cultured medium. The tissue was fixed in $3 \%$ gluteraldehyde, washed with a $0.05 \mathrm{M}$ potassium phosphate buffer $(\mathrm{pH} 7.0)$ and then dehydrated using ethanol. The sample was dried in a High Vacuum Evaporator (Hitachi-HUS 5GB). After gold plating, the sample was observed under a Scanning Electron Microscope (Hitachi S-3000).

\section{Stress Treatment}

Sodium chloride $(\mathrm{NaCl})$ was added to the MS medium and dissolved properly prior to $\mathrm{pH}$ maintenance. The callus was then exposed with different concentrations of sodium chloride. The various concentrations used were $T_{1}=25 \mathrm{mM}, \mathrm{T}_{2}=50 \mathrm{mM}$, $\mathrm{T}_{3}=75 \mathrm{mM}$ and $\mathrm{T}_{4}=100 \mathrm{mM} \mathrm{NaCl}$ and a control $\left(\mathrm{T}_{0}=0 \mathrm{mM}\right)$ was also kept for comparison.

\section{HPLC}

\section{Extraction}

The collected callus material was dried at room temperature for 1-2 weeks. The dried samples were ground using a pestle and mortar. Powder samples weighing $0.5 \mathrm{~g}$ were placed in a $50 \mathrm{ml}$ conical flask containing $10 \mathrm{ml}$ of Petroleum Ether, frequently shaken for $1 \mathrm{~h}$, this process repeated, and finally the mixture was filtered using Watmann's filter paper. The solid residues were dried in a vaccum, $10 \mathrm{ml}$ of dichloromethane was added and then shaken regularly for $45 \mathrm{~min}$. Then, $0.5 \mathrm{ml}$ of $12.5 \%$ ammonium hydroxide was added followed by 15 min constant shaking. The cocktail was kept undisturbed for $30 \mathrm{~min}$ and the calli residues and the supernatant were preserved after filtration. About $10 \mathrm{ml}$ of HPLC grade dichlorometane was used to wash the calli residues and was later filtered. The filtrates were collected and the organic phase was allowed to evaporate to dryness in a vacuum at room temperature and then dissolved in $10 \mathrm{ml}$ of ethanol (70\%). The mixture was filtered using filter paper and then transferred to $2.0 \mathrm{ml}$ Eppendorf tubes. A few biochemical tests were carried out to confirm the presence of colchicine. An alcoholic solution of colchicine is red in colour when treated with ferric chloride $\left(\mathrm{FeCl}_{3}\right)$ and yellow in colour when treated with mineral acids.

\section{Instrumentation}

The analysis of the colchicine was done by using HPLC system called WATERS (Milford, USA) having Waters PDA 2998 series 
photodiode array detector set at wavelength range 190-800 $\mathrm{nm}$. The column from the Waters Spherisorb ${ }^{\circledR} \mathrm{C} 18$ bonded with $5 \mu \mathrm{m}(4.6 \times 250 \mathrm{~mm})$ accompanied with EMPOWER-2 software was utilized for collection and processing of chromatographic data. Ultrasonic cleaner (Steryl medi-equip systems) and water purification system ELIX 03 (MILLIPORE, USA) was also used.

\section{Sample Preparation}

Stock solution of colchicine (marker) of concentration $1 \mathrm{mg} / \mathrm{ml}$ was used. Other samples were dissolved in methanol and stored at a low temperature $\left(4^{\circ} \mathrm{C}\right)$ until used. Different dilutions of stock solution with methanol were used to obtain $100 \mu \mathrm{g} / \mathrm{ml}$ so as to get standard curve.

\section{Optimization of Chromatographic Conditions}

Separation of compounds by HPLC is largely governed by the type of mobile phase used and organic modifiers. Different compositions, combinations, flow rate of organic solvents and other chromatographic parameters were used to standardize the protocol for optimization. The mobile phase combination of $\mathrm{H}_{2} \mathrm{O}$ : $\mathrm{MeOH}$ : Formic acid in the ratio of 50: 50:0.1 with isocratic elution at flow rate of $1.0 \mathrm{ml} / \mathrm{min}$ was used and found to be the optimum combination. For colchicine, best resolution and sensitivity was obtained at $352 \mathrm{~nm}$. The chromatogram of sharp and symmetric peak of retention time 3.82 min was obtained under optimized conditions.

\section{Validation of Optimized Method}

After optimizing the chromatographic method, it was validated according to $\mathrm{ICH}$ guidelines for linearity, sensitivity, precision and recovery studies were carried out (ICH Guidelines, 1994; IC Guidelines, 1996).

\section{Calibration Curve (Linearity)}

The calibration curve linearity was drawn by using six different concentrations of colchicine (in triplicate) and the calibration curve was plotted in 1-100 $\mu \mathrm{g} / \mathrm{ml}$ of colchicine range. The curve was plotted by replicate analysis at all concentration levels and the linear relationship was established using the least square method with Microsoft ${ }^{\circledR}$ Excel program.

\section{Precision}

Intra-day and inter-day precision for the developed method were calculated as percent relative standard deviation (\% RSD). For intra-day precision, the experiments were repeated three times a day while for inter-day, three different days were considered. The concentration values for both intra-day and inter-day precision were calculated six times respectively and \% RSD was similarly computed.

\section{Detection and Quantification Limits (LOD and LOQ)}

Limits of detection and quantification were calculated by method based on standard deviation $(\sigma)$ and slope $(S)$ of calibration plot using formula $L O D=3.3 \sigma / \mathrm{S}$ and $\mathrm{LOQ}=10 \sigma / \mathrm{S}$.

\section{RESULTS}

Different explants viz. corms, leaves, perianths, filaments, anthers and seeds of $C$. luteum plants from different geographical locations were tested in MS medium. Callus initiation was only achieved from corm explant (Figure 1a) irrespective of source regions. Seeds showed no response even after physical scarification (rubbing with sand paper) as the seeds possess a hard seed coat. The leaf and anther were also noted to be non responsive. Anthers turned black after a week of inoculation, perianth showed slight puffiness at the base of attachment after two weeks of inoculation and filaments showed bulging after two weeks of incubation. Anther, perianth and leaf all failed to produce callus in tested media conditions.

Different concentrations and combinations of PGRs were tried for callus production. In the first sets of experiments, 2, 4-D alone and in combination with BAP was used. From Table 1, it is apparent that the low auxin and high cytokinin concentrations / ratios were more efficient in inducing callus and for further growth (Figure $1 \mathrm{~b}$ ). Of all the combinations tested, $2.0 \mathrm{mg} \mathrm{L}^{-1} 2$, 4-D + $4.0 \mathrm{mg} \mathrm{L}^{-1}$ BAP proved to have a good effect on callusing frequency. BAP alone had no effect on callus initiation. The induced callus initiated

Table 1. Callus induction (\%) from corm in C. luteum, MS medium was amended with below mentioned PGRs.

\begin{tabular}{lccc}
\hline \multirow{2}{*}{ PGR ( $\left.\mathbf{m g ~ L}^{-1}\right)$} & \multicolumn{3}{c}{ Callus induction (\%) } \\
\cline { 2 - 4 } $0.252,4-\mathrm{D}$ & $\mathbf{2}$ weeks & $\mathbf{4}$ weeks & $\mathbf{6}$ weeks \\
\hline $0.502,4-\mathrm{D}$ & $15.0 \pm 2.88^{\mathrm{a}}$ & $18.33 \pm 1.66^{\mathrm{a}}$ & $21.66 \pm 4.40^{\mathrm{b}}$ \\
\hline $1.02,4-\mathrm{D}$ & $18.33 \pm 1.66^{\mathrm{a}}$ & $20.00 \pm 5.00^{\mathrm{b}}$ & $41.66 \pm 1.66^{\mathrm{d}}$ \\
\hline $1.02,4-\mathrm{D}+2.0$ BAP & $35.00 \pm 2.88^{\mathrm{c}}$ & $41.66 \pm 3.33^{\mathrm{d}}$ & $43.33 \pm 1.66^{\mathrm{d}}$ \\
\hline $2.02,4-\mathrm{D}+4.0$ BAP & $21.66 \pm 1.66^{\mathrm{b}}$ & $23.33 \pm 1.66^{\mathrm{b}}$ & $26.66 \pm 1.66^{\mathrm{b}}$ \\
\hline $3.02,4-\mathrm{D}+6.0$ BAP & $53.33 \pm 3.33^{\mathrm{e}}$ & $61.66 \pm 1.66^{\mathrm{f}}$ & $76.66 \pm 1.66^{\mathrm{f}}$ \\
\hline LSD at $5 \%$ & $28.33 \pm 4.40^{\mathrm{b}}$ & $31.66 \pm 1.66^{\mathrm{c}}$ & $35.00 \pm 2.88^{\mathrm{c}}$ \\
\hline
\end{tabular}

Values are means \pm standard errors of 3 replicates. Within each column, values are followed by the same alphabet are not significantly different at $p \leq 0.05$ level according to LSD. 

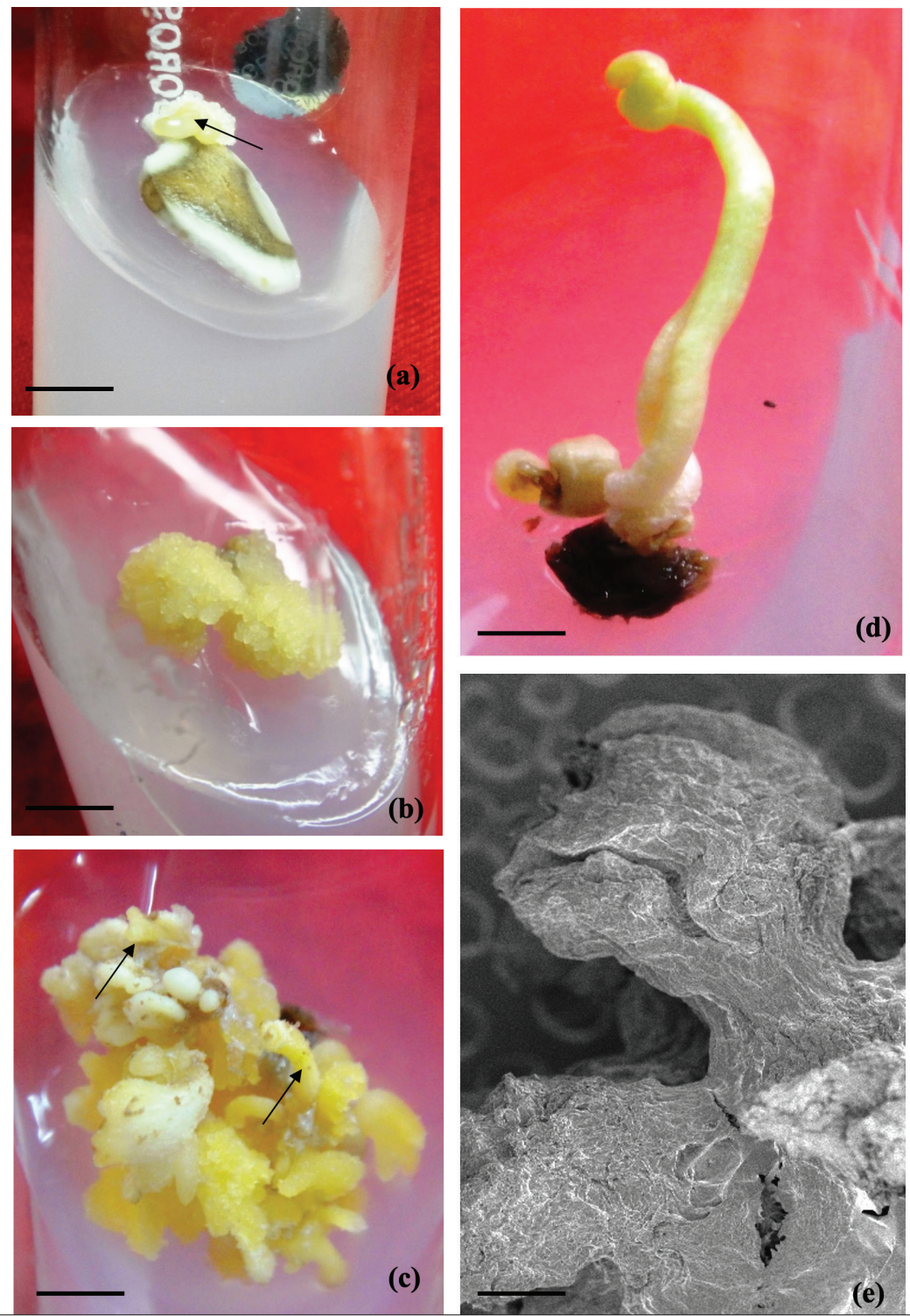

Figure 1. Callus induction, embryogenesis and plant regeneration in C. luteum (a) initiation of callus from corm explant (arrow) (b) callus proliferation (c) somatic embryos (arrows) (d) direct shoot regeneration and (e) SEM of somatic embryo. (Bar $1 \mathrm{a}-1 \mathrm{~d}=2 \mathrm{~mm} ; \mathrm{bar} 1 \mathrm{f}=300 \mu \mathrm{m})$.

from corm explant was yellowish, soft and exudated slimy viscous secretions. For a higher rate of callus initiation and proliferation, other methods using explant with $\mathrm{GA}_{3}$ and exposing the explant in red light (by providing a red transparent cover to the vial) was noted ineffective. Callus biomass growth/proliferation was observed in different PGR combinations and concentrations but the rate of growth was highest $(0.65 \mathrm{mg})$ in the $2.0 \mathrm{mg} \mathrm{L}^{-1} 2,4-\mathrm{D}+4.0 \mathrm{mg} \mathrm{L}^{-1}$ BAP (Figure 2) added medium. The initial amount of callus placed in the MS medium was $0.15 \mathrm{mg}$ and the biomass increase was monitored after 2, 4 and 6 weeks of culture. In order to adsorb phenolic exudates, various strategies like the addition of citric acid and activated charcoal were used as adjuvants. These adjuvants were added to the medium to see the influence of their effect on callusing and on growth by reducing callus browning, however, the response was noted to be non-promotive (Tables 2 and 3 ).

On sub culturing the callus on the same medium, the cormcallus transformed into embryogenic callus, which was distinctly different from non embryogenic tissue. Although the number of somatic embryos varied, on average 6-8 different stages of embryos (Figure 1c) were noticed per callus mass of about 200-300 mg. The number of embryos increased with each subculture. Moreover, the young corm-bud directly regenerated into shoots (Figure 1d) on MS medium. The embryo bearing callus was subjected to SEM studies to know more about the embryo details which revealed globular 


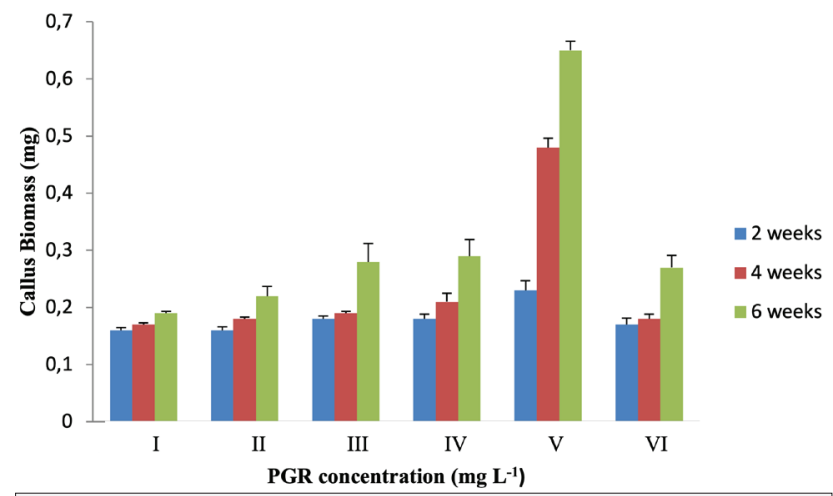

Figure 2. Callus biomass growth $(\mathrm{mg})$ in different concentrations and combinations of PGR. (I=0.25 2, 4-D; II = 0.502 2, 4-D; III = 1.0 $2,4-\mathrm{D} ; \mathrm{IV}=1.02,4-\mathrm{D}+2.0 \mathrm{BAP} ; \mathrm{V}=2.02,4-\mathrm{D}+4.0 \mathrm{BAP} ; \mathrm{VI}=3.0$ $2,4-D+6.0$ BAP) embryos with stalk present on the surface of the callus (Figure 1e). The embryo developed on embryogenic callus on sub culturing on shoot regeneration medium produced shoots (Table 4); the combination of $4.0 \mathrm{mg} \mathrm{L}^{-1} \mathrm{BAP}+2.0 \mathrm{mg} \mathrm{L}^{-1}$ NAA was noted to be the most efficient treatment for shoot development. For direct shoot regeneration, $2.0 \mathrm{mg} \mathrm{L}^{-1} \mathrm{BAP}$ $+2.0 \mathrm{mg} \mathrm{L}^{-1} \mathrm{NAA}$ supplemented medium was observed to be very effective (Table 5). All other treatments also showed some direct shoot regeneration ability with variable efficiency (33.33- $40.66 \%$ after $6^{\text {th }}$ weeks of culture).

The process of elicitation is an important technique to improve secondary metabolites in culture. Elicitors are molecules which activate plant defense mechanism and in turn improve alkaloid yield. In the present study, $\mathrm{NaCl}$ was used as an abiotic (salt) stress and the yield of colchicine was quantified in embryogenic

Table 2. Effect of adjuvants on callus induction percentage, MS medium was supplemented with $2.0 \mathrm{mg} \mathrm{L}^{-1} 2,4-\mathrm{D}+4.0 \mathrm{mg} \mathrm{L}^{-1} \mathrm{BAP}$

\begin{tabular}{lccc}
\hline & & \multicolumn{2}{c}{ Callus induction (\%) } \\
\cline { 2 - 4 } Adjuvants & 2 weeks & 4 weeks & 6 weeks \\
\hline Control (without adjuvant) & $53.33 \pm 1.66^{\mathrm{c}}$ & $61.66 \pm 1.66^{\mathrm{c}}$ & $76.66 \pm 1.66^{\mathrm{c}}$ \\
\hline Citric acid $\left(10 \mathrm{~g} \mathrm{~L}^{-1}\right)$ & $41.66 \pm 1.66^{\mathrm{a}}$ & $45.00 \pm 2.88^{\mathrm{a}}$ & $48.33 \pm 4.40^{\mathrm{a}}$ \\
\hline Activated charcoal $\left(1.0 \mathrm{~g} \mathrm{~L}^{-1}\right)$ & $45.00 \pm 2.88^{\mathrm{b}}$ & $45.00 \pm 2.88^{\mathrm{b}}$ & $51.66 \pm 3.33^{\mathrm{b}}$ \\
\hline LSD at $5 \%$ & 0.021 & 0.005 & 0.011 \\
\hline
\end{tabular}

Values are means \pm standard errors of 3 replicates. Within each column, values are followed by the same alphabet are not significantly different at $p \leq 0.05$ level according to LSD.

Table 3. Effect of adjuvants on callus biomass, MS was supplemented with $2.0 \mathrm{mg} \mathrm{L}^{-1} 2,4-\mathrm{D}+4.0 \mathrm{mg} \mathrm{L}^{-1} \mathrm{BAP}$ (initial weight $=0.15 \mathrm{mg}$ )

\begin{tabular}{lccc}
\hline & & \multicolumn{2}{c}{ Callus proliferation (mg) } \\
\cline { 2 - 4 } Adjuvants & $\mathbf{2}$ weeks & $\mathbf{4}$ weeks & $\mathbf{6}$ weeks \\
\hline Control (without adjuvants) & $0.20 \pm 0.02^{\mathrm{b}}$ & $0.30 \pm 0.02^{\mathrm{b}}$ & $0.58 \pm 0.01^{\mathrm{d}}$ \\
\hline Citric acid & $0.18 \pm 0.005^{\mathrm{a}}$ & $0.22 \pm 0.01^{\mathrm{b}}$ & $0.32 \pm 0.01^{\mathrm{c}}$ \\
\hline Activated charcoal & $0.19 \pm 0.005^{\mathrm{a}}$ & $0.21 \pm 0.008^{\mathrm{b}}$ & $0.23 \pm 0.006^{\mathrm{b}}$ \\
\hline LSD at $5 \%$ & 0.60 & 0.04 & 0.00 \\
\hline
\end{tabular}

Values are means \pm standard errors of 3 replicates. Within each column, values are followed by the same alphabet are not significantly different at $p \leq 0.05$ level according to LSD.

Table 4. Effect of BAP and NAA at below concentrations on shoot development ability from embryogenic callus in C. Iuteum.

\begin{tabular}{|c|c|c|c|}
\hline \multirow{2}{*}{ PGR (mg L-1) } & \multicolumn{3}{|c|}{ Shoot development rate (\%) } \\
\hline & 2 weeks & 4 weeks & 6 weeks \\
\hline 2.0 BAP+1.0 NAA & $36.66 \pm 1.66^{a}$ & $43.33 \pm 1.66^{b}$ & $46.66 \pm 1.66^{b}$ \\
\hline 4.0 BAP+2.0 NAA & $53.33 \pm 2.88^{c}$ & $60.00 \pm 2.88^{d}$ & $70.00 \pm 2.88^{d}$ \\
\hline 6.0 BAP+3.0 NAA & $38.33 \pm 4.40^{\mathrm{a}}$ & $41.66 \pm 3.33^{b}$ & $46.66 \pm 3.33^{b}$ \\
\hline LSD at $5 \%$ & 0.01 & 0.006 & 0.001 \\
\hline
\end{tabular}

Values are means \pm standard errors of at least 3 replicates. Within each column, values are followed by the same alphabet are not significantly different at $p \leq 0.05$ level according to LSD. 
Table 5. Shoots directly regenerated from corm explants in C. luteum, MS medium was amended with below PGR combinations and concentrations.

\begin{tabular}{|c|c|c|c|}
\hline \multirow{2}{*}{ PGR (mg L-1) } & \multicolumn{3}{|c|}{ Direct regeneration rate (\%) } \\
\hline & 2 weeks & 4 weeks & 6 weeks \\
\hline $1.02,4-\mathrm{D}+1.0 \mathrm{BAP}$ & $26.66 \pm 4.40^{\mathrm{a}}$ & $30.00 \pm 2.88^{b}$ & $36.66 \pm 4.40^{\mathrm{b}}$ \\
\hline $2.02,4-\mathrm{D}+2.0 \mathrm{BAP}$ & $23.33 \pm 3.33^{a}$ & $30.00 \pm 2.88^{b}$ & $35.00 \pm 2.88^{b}$ \\
\hline 3.0 2,4-D+3.0 BAP & $28.33 \pm 1.66^{a}$ & $35.00 \pm 3.33^{\mathrm{b}}$ & $40.66 \pm 2.88^{b}$ \\
\hline 1.0 BAP+1.0 NAA & $25.00 \pm 2.88^{a}$ & $28.33 \pm 1.66^{a}$ & $33.33 \pm 3.33^{b}$ \\
\hline 2.0 BAP+2.0 NAA & $55.00 \pm 2.88^{d}$ & $61.66 \pm 1.66^{\mathrm{e}}$ & $71.66 \pm 1.66^{f}$ \\
\hline 3.0 BAP+3.0 NAA & $31.66 \pm 1.66^{b}$ & $36.66 \pm 1.66^{b}$ & $40.00 \pm 2.88^{b}$ \\
\hline LSD at $5 \%$ & 0.00 & 0.00 & 0.01 \\
\hline
\end{tabular}

cultures as these tissues were more differentiated and supposed to synthesize alkaloids much than the undifferentiated, nonembryogenic callus. The HPLC chromatograms of standard and treated culture are presented in Figure 3 and Figure 4. Almost all the concentrations of $\mathrm{NaCl}$ improved colchicine in tissues, but the content was at its maximum in T3 (133.6 $\left.\mathrm{ng} \mathrm{mg}^{-1} \mathrm{DWB}\right)$, followed by T4 (106.6 ng mg ${ }^{-1}$ DWB) after $6^{\text {th }}$ weeks of culture.

$<$ Chromatogram>

mAU

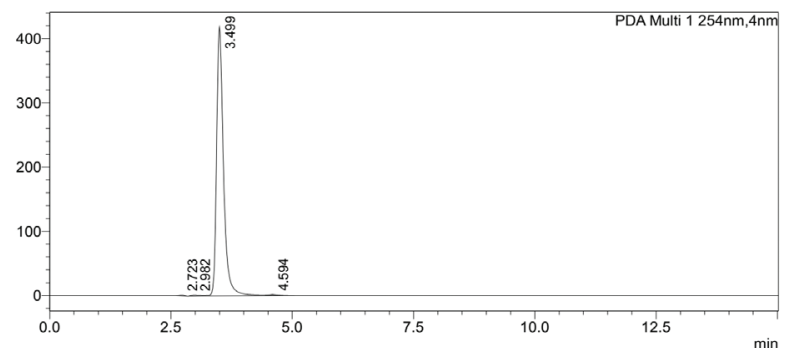

Figure 3. Chromatogram showing standard peak of colchicine.
As expected, the minimum level of colchicine was detected in $\mathrm{TO}$ i.e. $\mathrm{NaCl}$-free culture (Table 6). Results clearly indicate that the colchicine level improved with an increase in $\mathrm{NaCl}$ concentration, but at higher doses, the colchicine accumulation declined.

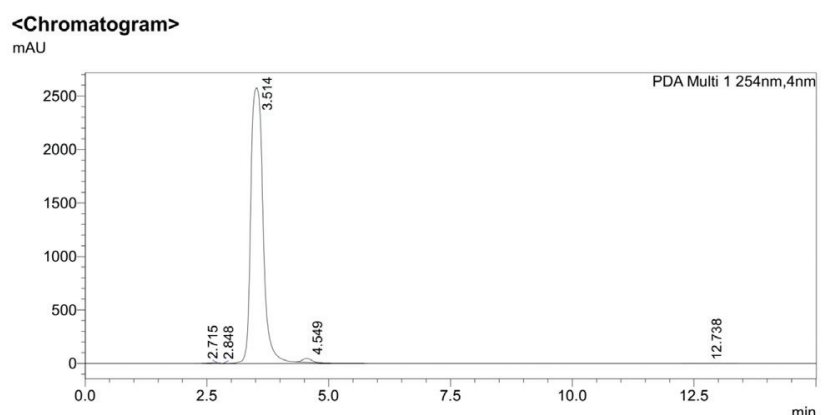

Figure 4. Chromatogram peak showing maximum yield of colchicine in salt treated cultures at $\mathrm{T}_{3}\left(\mathrm{~T}_{3}=75 \mathrm{mM}\right)$ in C. luteum.

Table 6. Effect of different concentrations of $\mathrm{NaCl}$ (salt) on colchicine content (ng $\mathrm{mg}^{-1} \mathrm{DWB}$ ) in C. luteum after regular interval of time ( 2 weeks, 4 weeks and 6 weeks)

\begin{tabular}{|c|c|c|c|}
\hline \multirow{2}{*}{$\mathrm{NaCl}$} & \multicolumn{3}{|c|}{ Colchicine content (ng mg-1 DWB) } \\
\hline & After 2 weeks & After 4 weeks & After 6 weeks \\
\hline $\mathrm{T}_{0}$ & $47.00 \pm 3.2^{b}$ & $55.00 \pm 6.0^{c}$ & $66.66 \pm 5.2^{c}$ \\
\hline $\mathrm{T}_{1}$ & $79.66 \pm 5.2^{c}$ & $85.33 \pm 4.0^{b}$ & $98.33 \pm 6.3^{c}$ \\
\hline $\mathrm{T}_{2}$ & $73.33 \pm 3.3^{b}$ & $87.33 \pm 6.1^{c}$ & $98.66 \pm 8.4^{d}$ \\
\hline $\mathrm{T}_{3}$ & $102.3 \pm 6.5^{c}$ & $112.0 \pm 5.6^{c}$ & $133.6 \pm 13.5^{f}$ \\
\hline $\mathrm{T}_{4}$ & $88.00 \pm 6.6^{c}$ & $101.0 \pm 7.9^{d}$ & $106.6 \pm 7.2^{c}$ \\
\hline LSD at $5 \%$ & 0.00 & 0.001 & 0.004 \\
\hline
\end{tabular}

Values are means \pm standard errors of 3 replicates. Within each column, values are followed by the same alphabet are not significantly different at $p \leq 0.05$ level according to $L S D$. ( $T_{0}=$ without $\mathrm{NaCl}, \mathrm{T}_{1}=25 \mathrm{mM}, \mathrm{T}_{2}=50 \mathrm{mM}, \mathrm{T}_{3}=75 \mathrm{mM}$ and $\left.\mathrm{T}_{4}=100 \mathrm{mM} \mathrm{NaCl}\right)$. 


\section{DISCUSSION}

In this present investigation, the impact of $\mathrm{NaCl}$ was studied on colchicine yield in in vitro raised tissues in C. luteum. Seeds are the primary source of explants, but here in this present study, the seeds did not germinate, even after stratification. Morteza et al. (10) reported similar response of no seed germination with stratification; hot temperature treatment, however, improved seed germination potentiality in C. kotschyi. As an alternative, other plant parts viz. leaves, corms, perianth, filaments and anthers were used for inducing callus and the corm was noted to be responsive only in producing callus. In another species of Colchicum (C. hierosolymitanum), callus was successfully induced from embryonic axis of seeds inoculated on $0.45 \mu \mathrm{M} 2$, 4- D supplemented medium (11). This explant-specific response is not new and has been noted in a large number of investigated cases (12). This differential callus forming ability may be due to the presence or absence of an endogeneneous level of PGRs and other physiological gradient in diverse explants (13). The callus was established in 2, 4-D added medium alone and in combination with BAP. The addition of PGRs particularly the auxin, was noted to be very promotive in producing callus in a number of studied plant materials $(14,15)$. With a few exceptions of brown callus, the callus was mostly pale yellow, moderately hard, compact and slimy in nature. The browning may have been due to exudates present in corm which leached out into the medium (11). This result is very similar to previous findings on Origanim vulgare L. where phenolic browning appeared after two weeks of callus incubation (16). Shweta et al. (17) reported that the addition of citric acid $\left(10.0 \mathrm{mg} \mathrm{L}^{-1}\right)$ in medium efficiently minimized the effect of phenolic exudation in C. luteum. In our present study, citric acid amendment had no significant effect on Colchicum cultures. The callus however, grew well and produced good amount of biomass (fresh weight) on increased concentration of BA $(9 \mu \mathrm{M})$ and 2, 4-D $(0.45 \mu \mathrm{M})$ in other investigated study and the observation (11) is similar and coincides with our present investigation.

The induced callus on sub culturing on the same 2,4-D containing medium transformed into embryogenic callus, distinctly different from non-embryogenic tissues on which a variable number of embryos were differentiated indirectly. No embryo was developed on the medium supplemented with NAA under light or dark conditions, a few embryos were, however, obtained on PGR- free medium. This indirect formation of embryo on callus was noted in several economically important plants (18). The influence of 2,4-D/auxins on induction of callus and later on embryo formation was reported in several investigated cases $(19,15)$. Nidal et al. (11) noted that the presence of $2,4-D$ alone or in combination with BA was very effective in inducing callus and promoting somatic embryo numbers in C. hierosolymitanum culture. In this present study, we observed embryogenic callus on 2, 4-D and BAP added medium, confirmed by SEM studies. Scanning electron microscopic study has been widely used for the establishment and confirmation of somatic embryo mediated plant regeneration in a number of plant systems $(20,21)$. The auxin's molecular role in inducing callus/embryo is not known fully but several lines of research suggested that auxins upregulate genes under stress situations in acquiring embryogenic competence $(22,23)$. Induced embryos matured and germinated into plants on a BAP added medium. The embryo germination/maturation is a key step in embryomediated propagation in which the addition of BAP or with NAA supplementation in medium facilitated plantlet production from embryos in other systems is used (24). The dormant corm bud was inoculated for shoot formation and within one or two weeks, outgrowths appeared as a first indicator of bud, which later turned into shoot primordia and grew moderately in the same BAP + NAA amended medium. Similar direct shoot primordial formation and their growth were noted in BAP, and with NAA added MS medium in many plants (25).

The present investigation was also conducted to see the impact of $\mathrm{NaCl}$ on colchicine yield in in vitro raised embryogenic tissues. The yield of colchicine was noted high in $\mathrm{NaCl}$ amended medium especially at T3. A similar enriched level of phyto-compounds following elicitation was reported in several investigated plant materials (26-28). The current study also revealed that the influence is dependent on $\mathrm{NaCl}$ concentration, the high to moderate level $(75 \mathrm{mM})$ was more responsive in promoting colchicine compared to low $\mathrm{NaCl}$ levels ( $25 \mathrm{mM}$ and $50 \mathrm{mM}$ ) and control. Earlier, in a similar approach Al- Fayyad et al. (29) quantified colchicine yield in corms $(0.052 \%)$, flowers $(0.025 \%)$ and leaves $(0.013 \%)$ in Colchicum hierosolymitanum by using different NPK fertilizer levels. In this species (C. hierosolymitanum), the maximum yield of colchicine was also noted in callus added to $30 \mathrm{mM} \mathrm{NH}_{4}$ and $0.1 \mathrm{M}$ of sucrose (30). Sivakumar et al. (31) described the importance of biorhizomes, rhizome specific genes/gene which over expressed in rhizomes for the biomanufacture of colchicine as root, callus and cell suspension of G. superba and various species of Colchicum yielded poor level of colchicine. It is believed that the synthesis of colchicine and colchicoside, a related secondary metabolite are often controlled by various external factors; our results thus indicate that $\mathrm{NaCl}$ could be a good inducer in improving colchicine yield, therefore of huge practical applications. The synthesis of alkaloid has been noted to be more in differentiated embryogenic tissue and at the onset of somatic embryo formation (marked by the appearance of procambial tissue and rudiments of transport systems like vascular elements), the synthesis of alkaloids begins, this indicates that the yieldcontent of alkaloid is directly related with embryogenesis (32). How and why synthesis is variable in different plant parts is still not known, some future experiments dealing with genes participating colchicine biosynthesis may help in unraveling the fact.

\section{CONCLUSION}

For callus induction, corm pieces proved to be the suitable explant, which produced callus on $0.5 \mathrm{mg} \mathrm{L}^{-1} 2,4-D$ and $0.5 \mathrm{mg} \mathrm{L}^{-1} \mathrm{BAP}$ added MS medium. In C. luteum, the combination of low auxin and high cytokinin concentration are necessary compared to the auxin alone. The growth of callus at the beginning is, however, slow. The induced callus transformed 
into embryogenic tissue and later produced somatic embryos. The recent study suggests sodium chloride is a potential inducer in improving colchicine yield in C. luteum.

Peer-review: Externally peer-reviewed.

Author Contributions: Conception/Design of study: M.M., Z.A.K.; Data Acquisition: M.M., M.K., T.A.W.; Data Analysis/ Interpretation: M.M., M.K., A.M.; Drafting Manuscript: M.M., M.K., Z.A.K., A.M.; Critical Revision of Manuscript: M.M., Z.A.K., A.M.; Final Approval and Accountability: M.M., M.K., Z.A.K., A.M., T.A.W.; Supervision: M.M., Z.A.K., A.M.

Conflict of Interest: The authors declare that they have no conflicts of interest to disclose.

Financial Disclosure: There are no funders to report for this submission.

\section{REFERENCES}

1. Kumar GP, Kumar R, Chaurasia OP, Singh SB. Current status and potential prospects of medicinal plant sector in trans-Himalayan Ladakh. J Med Plants Res 2011; 5: 2929-40.

2. Bashir A. Antioxidant activity and phenolic compounds from Colchicum luteum Baker (Liliaceae). Afr J Biotechnol 2010; 9: 5762-6.

3. Wechsler B. Colchicine and Behcet's disease: An efficiency enfinreconnue! (Behcet's disease and colchicines: An efficacious treatment finally recognized. J Med Int 2002; 23: 355-6.

4. Sakarkar DM, Deshmukh VN. Ethno pharmacological review of traditional medicinal plants for anticancer activity. Int J Pharm Tech Research 2011; 3: 298-308.

5. Azmat A, Ahmed KZ, Tariq B. Antinocciceptive effects of poly herbal oil extract. Pak J Pharmacy 2006; 23: 1-7.

6. Al-Fayyad M. Study of morphological characteristics, colchicine content and genetic variation of two wild Colchicum species in Jordan. Ph.D. Thesis, University of Jordan, Amman, Jordan. 2001.

7. Inchem. Colchicum autumnale L. Accessed on line at website: http:// www.inchem. rg/documents/ ims/plant/ im142.htm. 2006; PP: 1-33.

8. Naz R, Anis M. Acceleration of adventitious shoots by interaction between exogenous hormone and adenine sulphate in Althaea officinalis L. Appl Biochem Biotechnol 2012; 168:1239-55.

9. Murashige T, Skoog F. A revised medium for rapid growth and bioassay with tobacco tissue cultures. Physiol Plant 1962; 15: 473-97.

10. Morteza AN, Hossein A, Shamsali R, Mahmoud S, Yahya S, Navid VM. Warm stratification and chemical treatments overcome the dormancy and promotes germination of Colchicum kotschyi Boiss seeds under in vitro condition. Not Sci Biol 2011; 3: 104-7.

11. Nidal QD, Rida AS, Ibrahim MM, Feras A, Tamara SA. Callus Culture and Somatic Embryogenesis in Wild Colchicum hierosolymitanum Feib. Jordan J Agricultural Sciences 2012; 8: 536-56.

12. Ling APK, Tan KP, Hussein S. Comparative effects of plant growth regulators on leaf and stem explants of Labisia pumila var. alata. J Zhejiang Univ Sci B 2013; 14: 621-31.

13. Ghosh S, Sengupta S, Pal A. Abscisic acid, one of the key determinants of in vitro shoot differentiation from cotyledons of Vigna radiate. Amer J PI Sci 2014; 5: 704 -13.

14. Su YH, Zhao XY, Liu YB, Zhang CL, O'Neill SD, Zhang X. Auxininduced WUS expression is essential for embryonic stem cell renewal during somatic embryogenesis in Arabidopsis. Plant J 2009; 59: 448-60.
15. Fehér A. Somatic embryogenesis - Stress-induced remodeling of plant cell fate. Biochim Biophys Acta 2015; 1849(4): 385-402.

16. Arafeh RM, Shibli RA, Al-Mahmoud M, Shatnawi MA. Callusing, cell suspension culture and secondary metabolites production in Persian Oregano (Origanum vulgare L.) and Arabian Oregano (O. syriacum L.). Jordan J Agri Sci 2006; 2: 274-82.

17. Shweta S, Madhuparna B, Haider ZA. Conservation of Colchicum luteum Baker through micropropagation. J Research (BAU) 2013; 25: 96-100.

18. Gao F, Yong Y, Dai C. Effects of endophytic fungal elicitor on two kinds of terpenoids production and physiological indexes in Euphorbia pekinensis suspension cells. J Med Plants Res 2011; 5: 4418- 25.

19. Yang JL, Seong ES, Kim MJ, Ghimire BK, Kang WH, Yu CY, et al. Direct somatic embryogenesis from pericycle cells of broccoli (Brassica oleracea L. var. italica) root explants. Plant Cell Tiss Org Cult 2010; 100: 49-58.

20. Aslam J, Mujib A, Sharma MP. Somatic embryogenesis in Catharanthus roseus: a scanning electron microscopic study. Not Sci Biol 2015; 6 (2): 167-72.

21. Wang HC, Chen JT, Chang WC. Morphogenetic routes of long-term embryogenic callus culture of Areca catechu. Biol Plant 2010; 54:1-5.

22. Gliwicka M, Nowak K, Balazadeh S, Mueller-Roeber B, Gaj MD. Extensive modulation of the transcription factor transcriptome during somatic embryogenesis in Arabidopsis thaliana. PLoS ONE 2013; 8: e69261. doi: 10.1371/journal.pone.0069261.

23. Bai B, Su YH, Yuan J, Zhang XS. Induction of somatic embryos in Arabidopsis requires local YUCCA expression mediated by the down-regulation of ethylene biosynthesis. Mol Plant 2013; 6: 1247-60.

24. Mujib A, Ali M, Dipti T, Zafar N. Embryogenesis in ornamental monocots: Plant growth regulators as signaling element. In: Mujib, A., (ed). Somatic embryogenesis in ornamentals and its applications, Springer 2016 pp: 187-201.

25. Ashraf MF. Effect of cytokinin types, concentrations and their interactions on in vitro shoot regeneration of Chlorophytum borivilianum Sant. \& Fernandez. Electronic J Biotech 2014; 7: 275-9.

26. Ramakrishna A, Ravishankar GA. Influence of abiotic stress signals on secondary metabolites in plants. Plant Signal Behav 2011; 6: 1720-31.

27. Ribkahwati Purnobasuki $\mathrm{H}$, Isnaeni Utami ESW. Quantity essential oil from rose callus leaf (Rosa hybrid L. variety Hybride tea purple): Results of light elicitation. J Chem Pharma Res 2015; 7: 496-9.

28. Samar F, Mujib A, Tonk D. $\mathrm{NaCl}$ amendment improves vinblastine and vincristine synthesis in Catharanthus roseus: a case of stress signalling as evidenced by antioxidant enzymes activities. Plant Cell Tissue Org Cult 2015; 121: 445-58.

29. Al-Fayyad M, Alali F, Alkofali A, Tell A. Determination of colchicine content in Colchicum hierosolymitanum and Colchicum tunicatum under cultivation. Nat Prod Let 2002; 16: 395-400.

30. Daradkeh NQ, Shibli RA, Makhadmeh IM, Alali F, Al-Qudah TS. Cell suspension and in vitro production of colchicine in wild colchicum hierosolymitanum Feib. TOPROCJ (2012); 3: 52-9. 10.2174/1876326X01203020052.

31. Sivakumar G, Alba K, Phillips GC. Biorhizome: A Biosynthetic Platform for Colchicine Biomanufacturing. Front Plant Sci 2017; 8: 1137.

32. Tatiana YG, Valeria PG, Dmitry VB, Galina KT, Victor PB. Tempo-spatial pattern of stepharine accumulation in Stephania glabra morphogenic tissues. Int J Mol Sci 2019; 20: 808, doi:10.3390/ijms20040808. 